\title{
Analisis Keterampilan Dasar Mengajar Guru Dalam Perspektif Guru Pamong Pada Mahasiswa Prodi PGMI Fakultas Ilmu Tarbiyah dan Keguruan UIN Raden Fatah Palembang
}

Fakultas Ilmu Tarbiyah dan Keguruan

Universitas Islam Negeri Raden Fatah Palembang

Email :Nurlaili_uin@radenfatah.ac.id

\section{ABSTRAK}

Praktik Pengalaman Lapangan Kependidikan II merupakan pengalaman mengajar bagi mahasiswa sebagai gambaran akan tugas-tugas guru secara praktis agar mahasiswa memperoleh bimbingan mengenai kependidikan. Guru yang profesional adalah guru yang memiliki seperangkat kompetensi (pengetahuan, keterampilan, dan perilaku) meliputi kompetensi pedagogik, kepribadian, sosial, dan kompetensi profesional. Oleh karena itu, PPLK merupakan pengalaman penting dalam menunjang pencapaian keterampilan mahasiswa sebagai seorang guru yang profesional.

Permsalahan dalam penelitian ini adalah bagaimana keterampian dasar mengajar mahasiwa PGMI dalam perspektif pamong, sedangkan tujuannya untuk mengetahui keterampilan dasar mengajar mahasiwa Prodi PGMI pada PPLK II dalam persepsi guru pamong. Metode penelitian yang digunakan adalah metode deskriptif karena penulis memaparkankan secara faktual dan objektif mengenai keterampilan mengajar mahasiswa berdasarkan hasil wawancara dengan guru (pamong), observasi, dan dokumentasi. Pendekatan yang dilakukan adalah pendekatan kualitatif untuk mendapatkan data lebih mendalam, kredibel dan bermakna sehingga tujuan penelitian dapat dicapai. Lokasi penelitian adalah Madrasah Ibtidaiyah se-Kota Palembang. Kesimpulan keterampilan terkategori cukup baik, yaitu keterampilan membuka dan menutup pelajaran serta keterampilan menjelaskan, sedangkan tergolong baik, yaitu keterampilan bertanya, memberi penguatan, dan mengadakan variasi.

\section{Kata Kunci: Persepsi Guru Pamong, Ketrampilan Dasar Mengajar}

\section{A. Pendahuluan}

Pendidikan pada hakikatnya merupakan suatu proses pembinaan dan pengembangan kepribadian manusia seutuhnya. Hal tersebut telah tertuang dalam tujuan pendidikan Islam yang menginginkan pembentukan pribadi muslim seutuhnya, mengembangkan seluruh potensi manusia baik jasmani maupun rohani. Selaras dengan hal ini Undang-undang Sistem Pendidikan Nasional No. 20 tahun 2003 menyebutkan bahwa fungsi dan tujuan pendidikan nasional adalah sebagai berikut:

"Pendidikan Nasional berfungsi mengembangkan kemampuan dan membentuk watak serta peradaban bangsa yang bermartabat dalam rangka mencerdaskan kehidupan bangsa, bertujuan untuk berkembangnya potensi peserta didik agar menjadi manusia yang beriman dan bertakwa kepada Tuhan yang Maha Esa, berakhlak mulia, sehat, 
berilmu, cakap, kreatif, mandiri, dan menjadi warga Negara yang demokrasi dan bertanggung jawab".( UU SISDIKNAS)

Terwujudnya tujuan pendidikan nasional tersebut, maka pelaksanaan pendidikan amat dituntut tanggung jawabnya, pelaksanaan pendidikan sangat erat kaitannya dengan pengajaran. Kegiatan pembelajaranakan melibatkan berbagai komponen antara lain guru, peserta didik, dan faktor pendukung lainnya, apabila salah satu komponen tidak berfungsi dengan baik, maka kegiatan pengajaran akan tergangu sehingga pencapaian tujuan pendidikan tidak akan tercapai.

Salah satu upaya untuk dapat membentuk seorang guru yang profesional, Universitas Islam Negeri Raden Fatah Palembang sebagai salah satu Lembaga Pendidikan Tenaga Kependidikan (LPTK) yang khusus mengkader dan bertanggung jawab menghasilkan lulusan sebagai calon guru yang memiliki kemampuan dan keterampilan profesional, dan untuk meningkatkan mutu lulusannya, telah mewajibkan bagi seluruh mahasiswa program kependidikan untuk melaksanakan Praktik Pengalaman Lapangan Kependidikan (PPLK) dan salah satunya adalah mahasiswa Program Studi Pendidikan Guru Madrasah Ibtidaiyah (PGMI) pada Fakultas Ilmu Tarbiyah dan Keguruan.

PPLK pada Fakultas Ilmu Tarbiyah dan Keguruan adalah "Mata kuliah wajib yang harus ditempuh mahasiswa dalam menyelesaikan studinya. Mata kuliah ini mengandung bobot 4 sks dan mahasiswa yang berhak mengikuti mata kuliah ini bila telah selesai mengikuti mata kuliah PPLK I dengan standar kelulusan nilai B (score 70).” (Pedoman PPLK II 2012:4)

Menurut Wardani \& Suparno, Kegiatan Program Pengalaman Lapangan Kependidikan (PPLK) adalah kegiatan yang mencakup semua kegiatan dari mulai merencanakan, mengorganisasikan serta mempersiapkan segala sesuatunya sehingga tujuan program tercapai. (Wardhani dan Suparno 1994:21)

Selama kegiatan PPLK II ini berlangsung, mahasiswa dituntut untuk memiliki kemampuan dan keterampilan sebagai seorang guru yang profesional. Guru yang profesional adalah guru yang memiliki seperangkat kompetensi (pengetahuan, keterampilan, dan perilaku). Adapun kompetensi yang harus dimiliki oleh guru berdasarkan Undang-Undang Nomor 14 Tahun 2005 tentang Guru dan Dosen pada Bab IV Pasal 10 ayat 91), yang menyatakan bahwa "Kompetensi guru meliputi kompetensi 
pedagogik, kompetensi kepribadian, kompetensi sosial, dan kompetensi profesional yang diperoleh melalui pendidikan profesi”.(UU NO 14 Tahun 2005) Dan diharapkan mahasiswa yang akan melakukan kegiatan PPLK II memiliki gambaran yang jelas akan tugas-tugas yang dijalaninya, serta bukan hanya berkesempatan menerapkan pengalaman teoritis dan praktik saja, tetapi juga akan memperoleh pengalamanpengalaman baru yang mungkin tidak didapatkan dalam teoretis dan praktik, dalam kegiatan PPLK II tersebut mahasiswa akan memperoleh bimbingan dan pamongan. Bimbingan akan diberikan oleh suvervisor atau Dosen Pembimbing Lapangan (DPL) dari Universitas Islam Negeri Raden Fatah Palembang dan pamongan akan diberikan oleh Guru Pamong (guru yang ditunjuk sekolah) dari sekolah latihan atau tempat mahasiswa melaksanakan kegiatan PPLK II.

Berdasarkan hal di atas, pada saat pelaksanaan PPLK, kemampuan dan keterampilan mahasiswa akan dinilai oleh guru pamong, Dalam menilai kemampuan dan keterampilan mahasiswa, guru pamong memiliki persepsi yang berbeda-beda, sebagaimana Sarlito menjelaskan bahwa "Persepsi merupakan kemampuan untuk membedakan, mengelompokkan, memfokuskan dan sebagainya yang selanjutnya diinterpretasi”. (Sarlito 2009:85)

Persepsi guru pamong berbeda-beda karena banyak faktor yang dinilai antara lain, guru pamong melihat keterampilan mahasiswa praktik dalam melaksanakan pembelajaran, mahasiswa praktik kurang disiplin, dan kurang sesuai dalam menjalankan program semester dengan apa yang ada pada silabus, sering melalaikan tugas, tidak membuat RPP sebelum mengajar, tidak adanya ujian ulang bagi nilai yang tidak mencukupi standar yang telah ditentukan.

Berdasarkan wawancara pendahuluan kepada beberapa guru pamong mengenai persepsi mereka terhadap kegiatan mahasiswa PPLK terdapat persepsi negatif tentang kemampuan dan keterampilan mengajar mereka, di antaranya terlihat mahasiswa belum memiliki kesiapan dalam mengajar, kurang percaya diri, kurang menguasai materi, mahasiswa juga kurang memiliki kemampuan dalam mengelola kelas, serta membangkitkan motivasi siswa dalam belajar, dan sebagian besar mahasiswa PPLK juga kurang mampu menunjukkan rasa tanggung jawab yang tinggi.

Tingginya persepsi yang kurang baik oleh guru pamong mengenai kemampuan dan keterampilan mahasiswa PPLK, menunjukkan bahwa sebagian besar mahasiswa 
belum siap untuk mengikuti kegiatan PPLK. Persepsi guru pamong merupakan salah satu hasil yang dapat digunakan untuk menentukan keberhasilan mahasiswa dalam mengikuti kegiatan PPLK, hal ini dikarenakan guru pamong merupakan pendidik yang selalu berinteraksi dengan mahasiswa PPLK dalam proses pembelajaran, bila dibandingkan dengan Dosen Pembimbing lapangan (DPL) dari jurusan atau program studi. Oleh sebab itu, peneliti tertarik meneliti "Keterampilan Dasar Mengajar Guru dalam Persepsi Guru Pamong pada Mahasiswa Prodi PGMI Fakultas Tarbiyah UIN Raden Fatah Palembang".

\section{B. Metodologi Penelitian}

Jenis penelitian adalah penelitian kualitatif untuk menganalisis perspektif guru pamong terhadap keterampilan dasar mengajar guru, yaitu membuka menutup pelajaran,

memberi penguatan, keterampilan bertanya, keterampilan menjelaskan, dan keterampilan mengadakan variasi yang dilakukan mahasiswa saat melakukan PPLK II di Madrasah Ibtidaiyah.

Jenis data yang dipergunakan data kualitatif. Sumber data dalam penelitian ini diperoleh dari data primer adalah data dari informan, yaitu guru pamong se-Kota Palembang, sedangkan data sekunder berupa data yang diperoleh selama melaksanakan studi kepustakaan, berupa literatur maupun data tertulis yang berkenaan dengan penelitian yang akan diteliti. Teknik pengambilan sampel yang digunakan dalam penelitian ini adalah purposive sampling yaitu teknik pengambilan sampel sumber data dengan pertimbangan tertentu. Dalam hal ini informan yaitu guru pamong yang berkompeten berjumlah enam orang guru pamong, yaitu Madrasah Ibtidaiyah Negeri 1 satu orang, Madrasah Ibtidaiyah Negeri 2 berjumalh dua orang, Madrasah Ibtidaiyah Darul Aitam satu orang, dan Madrasah Ibtidaiyah Quraniyah 8 berjumlah dua orang.

Lokasi penelitian ini adalah Madrasah Ibtidaiyah se-Kota Palembang. Subjek penelitian adalah mahasiswa Prodi PGMI periode 2013/2014 yang melaksanakan PPLK II pada tahun 2016. Teknik pengumpuan data menggunakan wawancara, observasi, dan dokumentasi.

Analisis Data prosesnya diimulai dengan menelaah seluruh data yang tersedia dari berbagai sumber, baik dari observasi, wawancara, dan dokumen-dokumen yang berhubungan dengan penelitian seperti dokumen resmi maupun dokumen pribadi dan 
lain sebagainya. Dan data yang telah dikumpulkan dianalisis secara deskriptip kualitatif, yaitu menguraikan, menggambarkan, menyajikan, atau menjelaskan seluruh permasalahan yang ada secara tegas dan sejelas-jelasnya. Adapun analisis data dalam penelitian ini menggunakan langkah-langkah model Mills dan Huberman, yaitu reduksi data, display data, dan verifikasi.

\section{c. Hasil dan Pembahasan}

\section{a. Keterampilan Membuka dan Menutup Pelajaran}

Kegiatan Menutup dan membuka pelajaran adalah kegiatan guru untuk mengawali dan mengakhiri kegiatan inti pelajaran. Berdasarkan hasil wawancara kepada guru pamong diketahui bahwa keterampilan mahasiswa dalam membuka dan menutup pelajaran sudah cukup baik pada ketujuh aspek, yaitu menarik perhatian siswa, menimbulkan motivasi, memberi acuan, menunjukkan kaitan, meninjau kembali, mengevaluasi dan memberi dorongan psikologis/sosial.

Hasil pengamatan guru pamong diketahui bahwa kegiatan yang sering dilakukan oleh mahasiswa ketika menutup pelajaran, yaitu memberikan kesimpulan dan tugas. "Mahasiswa sudah berusaha memberikan kesimpulan, tugas maupun evaluasi (posttest) walaupun terkadang waktu yang tesedia hanya sedikit". Sebagaimana Hamdayama mengatakan "Guru harus merangkum dan membuat ringkasan inti pelajaran". (Jumanta Hamdayama,2016:75) Kegiatan menutup pelajaran dilaksanakan dengan mengajak siswa untuk menyimpulkan

Mahasiswa memiliki keterampilan membuka dan menutup pelajaran dengan baik karena sebagian besar "Mahasiswa mampu melakukannya, yaitu mahasiswa dapat mencuri perhatian peserta didik dengan menampilkan gaya mengajar guru yang bervariasi, menggunakan alat bantu dan mampu membuat suasana belajar yang bervariasi, dan pola interaksi yang dinamis serta antusias belajar peserta didik terugkap sehingga menimbulkan keingintahuan yang tinggi pada peserta didik selain itu peserta didik dapat mengikuti langkah-langkah pembelajaran yang sesuai prosedural penerapan suatu metode, mengaitkan mata pelajaran yang akan diajarkan dengan mata pelajaran sebelumnya, membuat ringkasan bersama peserta didik, dan melaksanakan evaluasi”.

Pendapat di atas sejalan dengan pendapat informan dari MIN 2 dan MIN Quraniyah 8 Pakjo Palembang. Tiga infoman menyatakan keterampilan mahasiswa 
membuka dan dan menutup pelajaran terkiategori cukup baik. Ini dapat dilihat dari calon guru dapat menarik perhatian tentang gaya, metode, media, dan peserta didik mengajukan pertanyaan. "Mahasiswa gaya mengajarnya tidak monoton jug menggunakan media buku tidak hanya buku paket juga menggunakan sumber buku lain. Penerapan metode dalam pembelajaan yang bervariasi serta pada akhir pembelajaran pun calon guru (mahasiswa) mengajukan pertanyaan kepada peserta didik sebagai pengukuran ketercapaiannya tujuan pembelajaran”. (Mustika,Wawancara 2017:22)

Demikian halnya dengan persepsi guru pamong Zn. Informan dari MI Darul Aitam bahwa keterampilan mahasiswa membuka dan menutup pelajaran terkategori cukup baik. Praktik mengajar yang dilakukan mahasiswa PPLK II Prodi PGMI pada saat membuka dan menutup pelajaran menunjukkan bahwa mahasiswa "Keterampilan membuka dan menutup pelajaran dalam pelaksanaannya masih terdapat kekurangan dan belum maksimal". (Zainab,wawancara:2017) hal ini terlihat pada saat membuka pelajaran mahasiswa PPLK II tidak memperhatikan gaya mengajarnya, setiap harinya saat membuka pelajaran menggunakan gaya yang sama, masuk ke kelas, menenangkan siswa sejenak lalu mengisi daftar hadir siswa dan langsung menjelaskan pelajaran. Hal seperti ini tidak dapat dikatakan sebagai keterampilan membuka pelajaran yang baik, seharusnya saat masuk ke kelas seorang guru sudah dalam kondisi siap untuk mengajar.

Apabila guru atau calon guru telah siap mengajar maka dalam membuka pelajaran guru atau calon guru seharusnya memperhatikan gaya mengajarnya sebagaimana pendapat Ali Mudlofir bahwasannya; keterampilan membuka pelajaran adalah perbuatan guru untuk menciptakan sikap mental dan menimbulkan perhatian anak didik agar berpusat pada yang akan dipelajari dan keterampilan menutup pelajaran adalah kegiatan yang dilakukan guru untuk mengakhiri pelajaran. (Ali Mudlofir,2012:83)

Keterampilan menutup pelajaran yang dilakukan mahasiswa PPLK II di MI Daarul Aaitam dapat dikategorikan kurang baik hal ini ditunjukkan dalam praktik mengajarnya pada saat menutup pelajaran. Mahasiswa PPLK II tidak membuat ringkasan ataupun merangkum inti pelajaran dikarenakan tidak bisa memperkirakan waktu. Berdasarkan data di atas keterampilan mahasiswa membuka dan menutup pelajaran cukup baik. 


\section{b. Keterampilan Menjelaskan}

Keterampilan mahasiswa menjelaskan materi dapat diketahui bahwa persepsi guru pamong Madrasah Ibtidaiyah Negeri 1 Teladan Palembang terhadap keterampilan menjelaskan pelajaran cukup baik.

Aspek-aspek penilaian terhadap keterampilan menjelaskan, yaitu a) orientasi dan motivasi yang meliputi bahan apersepsi, b) penggunaan bahasa yang sederhana dan jelas serta kesesuaian susunan kalimat, c) contoh yang digunakan banyak, konkret dan tepat, d) sistematika penjelasan yang memberikan tekanan suara dan gambar, e) variasi penyampaian dan metode yang digunakan, dan e) pertanyaan dan latihan sebagai balikan.

Berdasarkan hasil penilaian guru pamong dapat diketahui bahwa untuk aspek bahan apersepsi mahasiswa sudah baik dan jelas dalam memberikan orientasi dan motivasi terkait materi yang disampaikan. Pada aspek bahasa, mahasiswa sudah menggunakan susunan kalimat yang lebih sederhana dan mudah dipahami siswa.

Secara umum mahasiswa sudah menggunakan contoh dalam penyampaian materi pelajaran, namun memberian motivasi dan tekanan suara atau gambar masih perlu latihan. Hal tersebut dapat dilihat dari cara mahasiswa dalam menyampaikan materi. Mahasiswa sudah dapat mengembangkan materi yang disampaikan dan masih membaca teks, meskipun sudah dibantu dengan media pembelajaran.

Berdasarkan hasil penelitian dari kedua mahasiswa yang dilakukan oleh guru pamong ketika melaksanakan PPLK II diperoleh data yakni keterampilan menjelaskan dapat dikategorikan baik. Berdasarkan dengan pernyatan guru pamong ketika wawancara, yang menjelaskan bahwa mahasiswa PPLK sudah dapat dikatakan cukup baik ketika mengajar di kelas. Dalam memberikan penjelasan sudah menggunakan bahasa yang mudah untuk dipahami siswa juga sesuai pendapat Mudlofir "Penjelasan hendaknya diberikan dengan menggunakan bahasa yang mudah dimengerti oleh siswa". dan adanya variasi metode yang digunakan berikut dengan contoh-contoh yang digambarkan. Jadi, dapat disimpulkan bahwa rata-rata keterampilan menjelaskan mahasiswa ketika melaksanakan PPLK menurut persepsi guru pamong adalah cukup baik. 
Dari keenam guru pamong hanya satu guru pamong yang mengemukakan pendapat bahwa calon guru pada saat mengajukan pertanyaan kepada siswa kadangkadang kelas sering dalam keadaan gaduh sehingga tidak mendapat respon peserta didik. Hal lain menurut informan tersebut dalam memberikan tekanan suara calon guru masih monoton sehingga belum muncul dan tidak bervariasi. Calon guru dalam kelas belum nampak adanya interaksi timbal balik yang stabil antara kegiatan belajar dan mengajar dalam kelas. Interaksi belum terlihat dikarenakan posisi berdiri calon guru masih mendominasi di depan kelas. Jadi, berdasarkan informan di atas keterampilan calon guru dalam menjelaskan pelejaran kurang baik.

Pendapat dari satu informan di atas sama halnya dengan persepsi guru pamong di MI Daarul Aitam mengenai keterampilan menjelaskan pelajaran yang dilakukan mahasiswa PPLK II termasuk kurang baik, hal ini terlihat dari wawancara menjelaskan bahwa mahasiswa PPLK II "Perlu meningkatkan keterampilan menjelaskan pelajaran agar siswa lebih paham dalam menerima materi pelajaran. Penjelasan materi pelajaran yang jelas dan sistematis akan membuat siswa lebih mudah menerima dan memahami materi pelajaran". Pendapat senada dijelaskan oleh Uzer Usman "menjelaskan adalah usaha penyajian materi pembelajaran yang diorganisasikan secara sistematis". (Uzer Usman,2006:88)

\section{c. Keterampilan Bertanya}

Bertanya merupakan salah satu aktivitas yang selalu ada dalam proses komunikasi, memberi stimulus kepada siswa dalam bentuk kalimat tanya yang membutuhkan jawaban. Hasil wawancara dengan guru pamong, yakni keterampilan bertanya mahasiswa sudah berusaha dengan baik agar pertanyaan-pertanyaan yang diberikan kepada siswa dapat memotivasi siswa untuk terlibat aktif dalam interaksi belajar dikelas.

Pertanyaan yang dibuat oleh mahasiswa menggunakan bahasa yang sederhana dan mudah dipahami siswa sehingga merangsang siswa untuk berfikir dan berusaha mengungkapkan pendapatnya. Pernyataan tersebut sesuai dengan pendapat Hamdayana "Setelah mengajukan pertanyaan, guru perlu memberikan waktu kepada siswa untuk memikirkan jawaban yang atas pertanyaan terebut." (Jumanta Hamdan:78) Oleh karena 
itu, dalam pelaksanaan keterampilan bertanya ini guru pamong memberikan penilaian yang dapat dikategorikan baik.

Persepsi guru pamong di MI Daarul Aitam menunjukkan bahwa keterampilan bertanya yang dilakukan mahasiswa PPLK II sudah "Terlaksana dengan baik hal ini ditunjukkan pada saat memberikan pertanyaan dengan kata-kata yang jelas dan singkat sehingga siswa dapat mengerti arah dan maksud pertanyaan guru, guru juga memusatkan pertanyaan pada suatu fokus jawaban, dan dalam pemberian acuan atau pengarahan jawaban kepada siswa sudah terlaksana dengan baik ini terlihat ketika siswa merasa bingung dan kesulitan dalam menjawab pertanyaan, atau mungkin saja siswa tersebut memiliki lebih dari satu jawaban atas pertanyaan yang diberikan guru namun ragu untuk menentukan mana jawaban yang tepat atas pertanyaan yang telah diberikan oleh guru, maka guru sudah membantu memberikan informasi yang berkaitan dengan jawaban sehingga siswa merasa yakin atas jawabannya". Dari hasil penelitian ini dapat dibuktikan bahwa mahasiswa PPLK II dapat melaksanakan keterampilan bertanya dengan baik, dapat memberikan arahan atas materi yang disampaikan kepada siswa dan dapat membuat siswa lebih aktif dalam proses pembelajaran serta mengetahui seberapa jauh pemahaman siswa mengenai materi pelajaran yang telah disampaikan.

\section{d. Keterampilan Memberi Penguatan}

Penguatan adalah tanggapan guru terhadap perilaku siswa yang memungkinkan dapat membesarkan hati siswa agar lebih terpacu dalam interaksi pembelajaran. Dalam keterampilan memberi penguatan terdapat beberapa aspek yang dapat dilihat dan dijadikan sebagai penilaian oleh guru pamong terhadap kemampuan dan keterampilan dasar mengajar mahasiswa yaitu a) penguatan verbal baik mengunakan kata-kata maupun kalimat, b) penguatan nonverbal yang dapat berbentuk gerak- gerik, mimik, mendekati, sentuhan, tepuk pundak, pemberian symbol kegiatan yang menyenangkan, dll, c) cara pengunan penguatan baik segera maupun dengan adanya variasi penguatan, d) prinsip pengunaannya secara kehangatan, mermakna atau antusias.

Berdasarkan penelitian hal tersebut juga diperkuat dengan pernyatan guru pamong ketika wawancara, yang menjelaskan bahwa mahasiswa PPLK sudah dapat dikatakan baik ketika mengajar di kelas. "Dalam memberikan penguatan sudah ada penguatan yang berupa ucapan seperti "ya bagus nak, jawabanmu benar". Selain itu, ada yang berupa simbol seperti mengacungkan jempol, mimik wajah yang menunjukan 
keantusiasan, menepuk bahu dan lain sebagainya. "Cara pemberian penguatan pun bervariasi kadang diberikan secara langsung dan kadang berupa motivasi belajar yang bermakna".

\section{e. Keterampilan Variasi}

Variasi dapat diartikan sebagai keanekaan yang membuat sesuatu tidak monoton. Menurut Soetomo "Pemberian variasi dalam interaksi belajar mengajar diartikan sebagai perubahan pengajaran dari yang satu ke yang lain dengan tujuan untuk menghilangkan kebosanan dan kejenuhan siswa dalam menerima bahan pengajaran yang diberikan guru, sehingga siswa dapat aktif lagi dan berpartisipasi dalam belajarnya." (Sutomo, 1993:101)

Keterampilan variasi dalam mengajar pada penelitian ini mengenai variasi suara, mengarahkan perhatian siswa, adanya pause, kontak mata, ekspresi roman muka, gerakgerik tangan, tempet guru di kelas, variasi dalam pola interaksi dan variasi dalam apa yang dilihat-didengar-dikerjakan siswa.

\section{Simpulan}

1. Keterampilan mahasiswa membuka dan menutup pelajaran sudah cukup baik dalam menarik perhatian siswa, menimbulkan motivasi, memberi acuan, menunjukkan kaitan, meninjau kembali, mengevaluasi dan memberi dorongan psikologis/sosial hal ini dapat dilihat adanya suasana membuka dan menutup pembelajaran dengan semangat dan antusias belajar.

2. Keterampilan mahasiswa menjelaskan materi pelajaran cukup baik dalam mengorientasikan dan memberikan motivasi kepada siswa pada waktu melakukan bahan apersepsi, kemudian penggunaan bahasa yang sederhana dan jelas serta kesesuaian susunan kalimat, memberikan contoh yang digunakan banyak, konkret dan tepat, selanjutnya sistematika penjelasan memberikan tekanan suara dan gambar, bervariasi dalam pennggunaan metode, dan mengadakan pertanyaan dan latihan sebagai balikan.

3. Keterampilan mahasiswa mengajukan pertanyaan melaksanakan keterampilan bertanya dengan baik, dapat memberikan arahan atas materi yang disampaikan kepada siswa dan dapat membuat siswa lebih aktif dalam proses pembelajaran serta 
mengetahui seberapa jauh pemahaman siswa mengenai materi pelajaran yang telah disampaikan.

4. Keterampilan mahasiswa dalam pemberian penguatan baik, hal ini dapat dilihat dari aktivitas guru (mahasiswa) merespon kegiatan siswa baik berupa kata-kata atau gerakan-gerakan juga menciptakan kehangatan serta kebermaknaan dalam berlangsungnya proses pembelajaran.

Keterampilan mahasiswa dalam mengadakan variasi menurut guru pamong terkategori baik.

\section{Saran}

1. Mahasiswa agar lebih menguasai materi pelajaran secara luas dan mendalam serta kholistik serta mahasiswa dalam menjelaskan pelajaran sebaiknya logis dan sitematik dengan memberikan contoh-contoh yang didukung oleh berbagai variasi dan metode serta media pembelajaran.

2. Dosen saat mengajar di kelas lebih mengarahkan pada penekanan pembelajaran aktif sehingga terjadi pembelajaran interaktif yang kondusif antara pengajar dan pembelajar dengan tujuan agar mahasiswa mampu mengemukkan pendapat sehingga mahasiswa memiliki kemampuan keterampilan berbicara yang logis dan sistematis. 


\section{DAFTAR PUSTAKA}

Aqib, Zainal. 2015. Model-Model,Media,dan Strategi Pembelajaran Kontekstual. Bandung: Yrama Widya.

Arikunro, Suharsimi. 2006. Prosedur Penelitian: Suatu Pendekatan Praktek. Jakarta: Rineka Cipta.

Arikunto, Suharsimi. 2013. Prosedur Suatu Pendekatan Praktik, Cet.15. Jakarta: Rineka Cipta.

Bagman dan Taylor. 1995. Metodologi Penelitian Filsafat. Jakarta: Raja Grafindo Persada.

Bungin, Burhan. 2001. Metodologi Penelitian Sosial. Surabaya: Airlangga.

Departemen Pendidikan Nasional. 2007. Undang-Undang SISDIKNAS (Sistem Pendidikan Nasional). Jakarta: Sinar Grafika.

Elhefni, Ahmad Syarifuddin, dan Emi Kartina. 2011. Strategi Pembelajaran. Palembang: Grafika Telindo.

Fakultas Tarbiyah IAIN Raden Fatah. 2012. Pedoman Pelaksanaan PPLK II (Program Pengalaman Lapangan Kependidikan II). Palembang.

Hadi, Sutrisno 1983. Metodologi Research. Yogyakarta : Fakultas Psikologi UGM.

Hamdayama, Jumanta. 2016. Metodologi Pengajaran. Jakarta: Bumi Akasara.

JS. Husdarta dan Yudha M. Saputra. 2013. Belajar dan Pembelajaran Pendidikan Jasmani dan Kesehatan. Bandung: Alfabeta.

Majid, Abdul. 2013. Strategi Pembelajaran. Bandung: Remaja Rosdakarya.

Marno dan Idris. 2014. Stategi, Metode, dan Teknik Mengajar Menciptakan Keterampilan Mengajar yang Efektif \& Edukatif. Yogyakarta: Ar-Ruzz Media.

Moleong, Lexy J. 2005. Metode Penelitian Kualitatif. Bandung: Remaja Rosdakarya. 
Mudlofir, Ali. 2012. Pendidik Profesional. Jakarta: Raja Grafindo Persada.

Muhajir, Noeng. 1996. Metode Penelitian Kualitatif. Yogyakarta: Rake Sarasia.

Mulyasa. E. 2001. Menjadi Guru Profesional Menciptakan Pembelajaran Kreaif dan Menyenangkan. Bandung, Remaja Rosdakarya.

Sarwono, Sarlito. 2009. Pengantar Psikologi Umum. Jakarta: Rajawali Pers.

Suwarna. 2006. Pengajaran Mikro. Yogyakarta: Tiara Wacana.

Suyono dan Hriyanto. 2014. Belajar dan Pembelajaran Teori dan Konsep Dasar. Bandung: PT Remaja Rosdakarya.

Usman, Moh. Uzer. 2011. Menjadi Guru Profesional. Bandung: PT Remaja Rosdakarya.

Wardhani dan Suparno. 1994. Program Pengalaman Lapangan (PPL). Jakarta: Direktorat Jendral Pendidikan Tinggi Departemen Pendidikan dan Kebudayaan. 